\title{
Penerapan Model PBL dengan Metode Course Review Horay Berbantuan Media Crossword untuk Meningkatkan Aktivitas dan Hasil Belajar Siswa
}

\author{
Uswatun Hasanah*, Anik Anekawati, Dyah Ayu Fajarianingtyas \\ Pendidikan IPA, Universitas Wiraraja, Sumenep, Indonesia \\ Pengiriman:18/02/2020; Diterima: 06/10/2020; Publikasi: 20/11/2020 \\ DOI: 10.31629/kiprah.v8i2.2049
}

\begin{abstract}
Abstrak
Penelitian ini bertujuan untuk mengetahui penerapan model PBL dengan metode CRH berbantuan media crossword terhadap aktivitas dan hasil belajar IPA SMP. Penelitian ini merupakan jenis penelitian kuantitatif dengan metode penelitian, yaitu quasi experiment. Metode penelitian quasi experiment ini dilakukan pada kelas eksperimen dan kelas kontrol. Kelas eksperimen menggunakan penerapan model PBL dengan metode CRH berbantuan media crossword, sedangkan kelas kontrol menggunakan penerapan model PBL dengan metode ceramah. Teknik analisis data yang digunakan di antaranya adalah teknik analisis statistik Mann-Whitney untuk mengetahui aktivitas dan hasil belajar siswa. Berdasarkan hasil analisis data melalui instrumen penelitian berupa lembar pengamatan aktivitas belajar yang diperoleh, menunjukkan bahwa terdapat perbedaan aktivitas belajar siswa melalui penerapan model PBL dengan metode CRH berbantuan media crossword dan siswa melalui model PBL dengan metode ceramah, sedangkan untuk hasil belajar siswa melalui instrumen tes hasil belajar menunjukkan bahwa terdapat perbedaan hasil belajar antara kelas yang menggunakan model PBL dengan metode CRH berbantuan media crossword dan kelas yang menggunakan model PBL dengan metode ceramah.
\end{abstract}

Kata kunci: course review horay; crossword; problem based learning

\begin{abstract}
This study aims to determine the application of the PBL model with the CRH method assisted by crossword media to the activities and learning outcomes of junior high school science learning. This research is a type of quantitative research with a research method, namely a quasi-experiment. This quasi-experimental research method was carried out in the experimental class and the control class. The experimental class used the application of the PBL model with the CRH method assisted by crossword media while the control class used the application of the PBL model with the lecture method. The data analysis technique used includes the MannWhitney statistical analysis technique to determine student activity and learning outcomes. Based on the results of data analysis through research instruments in the form of observation sheets of learning activities obtained, it shows that there are differences in student learning activities through the application of the PBL model with the CRH method assisted by crossword media and students through the PBL model with the lecture method, while for student learning outcomes through the results test instrument learning shows that there are differences in learning outcomes between classes using the PBL model with the CRH method assisted by crossword media and the class using the PBL model with the lecture method.
\end{abstract}

Keywords: course review horay; crossword; problem based learning 


\section{PENDAHULUAN}

Ilmu Pengetahuan Alam (IPA) merupakan upaya menciptakan dan membangun pengetahuan tentang gejala alam (Widodo et al., 2017) berdasarkan pengamatan dan analisis data tentang gejala alam yang terjadi pada kehidupan sehari-hari (Widyanimade et al., 2014). IPA dalam pembelajarannya menekankan pada kegiatan pembelajaran yang berpusat kepada siswa (Zubaidah et al., 2017). Oleh karena itu, dalam kegiatan pembelajaran IPA diperlukan suatu cara belajar yang melibatkan aktivitas siswa (Aliwanto, 2017).

Aktivitas belajar merupakan keseluruhan aktivitas yang dilakukan siswa selama kegiatan belajar mengajar berlangsung (Kusumaningrum, 2013), melalui perencanaan untuk mencapai perubahan dengan menggunakan seluruh kemampuan siswa (Rusman, 2017). Aktivitas tersebut melibatkan sikap, pikiran dan perbuatan untuk menunjang keberhasilan proses belajar mengajar (Primasari, 2016). Penelitian Indrastuti et al., (2017) menunjukkan bahwa aktivitas belajar pada kegiatan mendengarkan dan bertanya dari siswa yang rendah, mengakibatkan hasil belajar rendah. Menurut Suana, (2016) yang menyatakan bahwa aktivitas belajar siswa pada kegiatan mengamati yang rendah akan mengakibatkan rendahnya hasil belajar.

Rendahnya aktivitas tersebut dikarenakan kurangnya keterlibatan siswa secara aktif dalam mendengarkan, bertanya, dan mengamati materi yang disampaikan guru (Indrastuti et al., 2017). Salah satu faktor yang memengaruhi rendahnya hasil belajar siswa adalah aktivitas siswa (Ayaz \& Sekerci, 2015). Berdasarkan pada pernyataan di atas, maka diperlukan suatu pembelajaran yang melibatkan aktivitas belajar siswa secara aktif sehingga hasil belajar siswa menjadi lebih baik, salah satunya melalui metode CRH (course review horay) berbantuan media crossword (teka teki silang).

Penerapan metode CRH yang dibantu dengan media crossword ini bertujuan untuk mengetahui aktivitas siswa dalam bekerja sama pada kegiatan belajar yang dilakukan seperti dalam kegiatan mendengarkan, bertanya, dan mengamati. Hal ini dikarenakan siswa seringkali tidak melakukan aktivitas tersebut melainkan melakukan kegiatan di luar aktivitas mendengarkan, bertanya, dan mengamati. Akibatnya, ketika melakukan kegiatan mengerjakan soal siswa merasa kesulitan dikarenakan kurangnya partisipasi siswa dalam aktivitas tersebut. Jika siswa mampu dalam melakukan aktivitas-aktivitas tersebut, akan mempermudah siswa ketika megerjakan soal-soal yang diberikan oleh guru, salah satunya adalah soal crossword.

Metode CRH merupakan suatu metode pembelajaran untuk mengetahui pemahaman konsep siswa menggunakan soal yang diletakkan di dalam kotak, jika siswa mampu menjawab soal dengan benar maka harus berteriak "hore" (Budiyanto, 2016). Metode CRH juga merupakan metode pembelajaran yang dapat meningkatkan pemahaman siswa dengan cara meminta siswa menjawab pertanyaan di dalam kotak (Meganingtyas et al., 2019).

Putri et al., (2017) menyatakan bahwa metode CRH dilakukan untuk menguji pemahaman siswa menggunakan kotak yang terdiri dari jumlah huruf pada jawaban. Siswa yang mendapatkan jawaban benar harus berteriak "hore". Metode $\mathrm{CRH}$ dalam penelitian ini dilakukan agar aktivitas siswa seperti dapat mengalihkan topik pembicaraan lebih fokus pada materi pembelajaran. Penerapan metode CRH tersebut dibantu dengan penggunaan media crossword untuk mengetahui aktivitas belajar siswa dalam mendengarkan, bertanya, dan mengamati pelajaran.

Crossword merupakan sebuah permainan yang menyenangkan dalam kegiatan pembelajaran, serta memberikan banyak kesempatan siswa untuk berlatih dan mengulangi materi pelajaran (Puspita \& Sabiqoh, 2017). Selain itu, crossword juga membantu proses pembelajaran yang dilakukan guru untuk menghilangkan 
kebosanan siswa dalam kegiatan belajar (Merkel, 2016). Metode CRH dengan bantuan media crossword dilakukan melalui pemberian soal teka-teki silang yang bertujuan meningkatkan aktivitas dan melatih pemahaman siswa terhadap materi yang dipelajari sebelum mengerjakan soal hasil belajar.

IPA dipelajari berkaitan dengan peristiwa yang melibatkan kehidupan seharihari, bukan hanya dengan cara menghafal materi. Widyanimade et al., (2014) menyatakan bahwa pembelajaran IPA berdasarkan pada pengamatan dan analisis data terhadap gejala alam yang terjadi di kehidupan sehari-hari. Oleh karena itu, salah satu upaya yang dapat diterapkan dengan metode CRH berbantuan media crossword, yaitu melalui model PBL (Problem Based Learning).

Model PBL merupakan pembelajaran yang berpusat pada masalah. Siswa diberikan sebuah permasalahan terkait masalah nyata dalam kehidupan sehari-hari (Kim et al., 2018). PBL didasarkan pada pengalaman, kerjasama, kontekstual, dan teori pembelajaran konstruktivisme yang bertujuan memperoleh informasi baru (Korpi et al., 2018). Menurut Lee \& Blanchard. (2018) PBL berbeda dengan menghafal karena PBL secara inovatif dapat meningkatkan kemampuan menyerap, memahami, mempertahankan, dan menggunakan informasi siswa dalam pembelajaran selanjutnya.

Model PBL yang dilakukan akan menjadi lebih hidup jika dalam penerapannya dibantu dengan metode dan media pembelajaran yang bermakna dan menyenangkan bagi siswa. Menurut Dewi et al. (2014) "penggunaan metode/media dalam pembelajaran yang diselingi dengan hiburan akan membuat suasana belajar menjadi menyenangkan dan siswa lebih semangat untuk mengikuti pembelajaran".

Model PBL yang digunakan dalam penelitian ini dilaksanakan dengan metode CRH berbantuan media crossword untuk mengetahui 1) ada perbedaan aktivitas belajar kelas eksperimen dan kontrol; 2) ada perbedaan hasil belajar antara kelas eksperimen dan kelas kontrol.

\section{METODE PENELITIAN}

Penelitian ini merupakan jenis penelitian kuantitatif dengan metode quasi experiment untuk mengetahui apakah ada perbedaan aktivitas belajar dan hasil belajar antara kelas eksperimen dengan dan kontrol. Penelitian ini diimplementasikan pada siswa kelas VII di SMP Plus Miftahul Ulum yang terdiri dari 2 kelas, yaitu siswa kelas eksperimen yang menggunakan model PBL dengan metode $\mathrm{CRH}$ berbantuan media crossword dan siswa kelas kontrol yang menggunakan model PBL dengan metode ceramah. Desain penelitian yang digunakan adalah nonequivalent control group design.

\begin{tabular}{|lll|}
\hline$O_{1}$ & $X_{1}$ & $O_{2}$ \\
$O_{3}$ & $X_{2}$ & $O_{4}$ \\
\hline
\end{tabular}

Gambar 1. Desain Penelitian Nonequivalent Control Group Design (Sugiyono, 2013)

Keterangan:

$\mathrm{O}_{1} \quad$ : Pretest kelas eksperimen

$\mathrm{O}_{2} \quad$ : Posttest kelas kontrol

$\mathrm{X}_{1} \quad$ : Penerapan model PBL dengan metode CRH berbatuan media crossword pada kelas eksperimen

$\mathrm{X}_{2} \quad$ : Penerapan model PBL dengan metode ceramah pada kelas kontrol

$\mathrm{O}_{3} \quad$ : Pretest kelas eksperimen

$\mathrm{O}_{4} \quad$ : Posttest kelas kontrol

Instrumen penelitian yang digunakan dalam penelitian ini meliputi lembar pengamatan aktivitas belajar dan lembar tes hasil belajar siswa. Teknik analisis data yang digunakan merupakan teknik analisis statistik Mann-Whitney karena data yang diperoleh tidak berdistribusi normal. Sebelum menggunakan analisis data statistik aktivitas belajar dilakukan uji prasyarat yaitu melalui uji normalitas. Sementara itu, sebelum melakukan analisis data hasil belajar menggunakan statistik dilakukan pengolahan data menggunakan uji prasyarat yang meliputi 
validitas soal, reliabilitas soal, tingkat kesukaran soal, dan uji normalitas.

\section{HASIL DAN PEMBAHASAN}

\section{Aktivitas Belajar}

Aktivitas belajar siswa di kelas selama pembelajaran berlangsung yang diamati oleh pengamat $1(\mathrm{P}-1)$ dan pengamat $2(\mathrm{P}-2)$ baik kelas eksperimen ataupun kontrol dapat dilihat dari hasil uji Mann-Whitney pada Tabel 1 berikut

Tabel 1 Hasil Uji Statistik Mann-Whitney Pada Aktivitas Belajar Siswa

\begin{tabular}{lr}
\multicolumn{2}{c}{ Test Statistics $^{\mathbf{a}}$} \\
\hline \multicolumn{2}{c}{ Nilai } \\
\hline Mann-Whitney U & 32.000 \\
Wilcoxon W & 110.000 \\
Z & -2.419 \\
Asymp. Sig. (2-tailed) & .016 \\
Exact Sig. [2*(1-tailed Sig.)] & $.020^{\mathrm{b}}$ \\
\hline
\end{tabular}

Tabel 1 di atas menunjukkan bahwa hasil uji Mann-Whitney didapatkan nilai signifikansi sebesar 0,016 kurang dari 0,05, artinya ada perbedaan antara aktivitas belajar kelas yang menggunakan model PBL dengan metode CRH berbantuan media crossword dengan kelas yang menggunakan model PBL dengan metode ceramah. Aktivitas belajar yang diamati oleh pengamat meliputi indikator dari aktivitas belajar, yaitu mendengarkan, bertanya, dan mengamati.

Aktivitas mendengarkan untuk siswa kelas PBL dengan metode CRH berbantuan media crossword lebih baik dibandingkan siswa kelas PBL dengan metode ceramah. Hal tersebut dikarenakan siswa begitu antusias dalam rasa ingin tahunya terhadap hasil diskusi siswa yang mempresentasikan jawaban soal analisis gambar maupun video. Jika rasa ingin tahu siswa terhadap penjelasan guru dan hasil diskusi siswa begitu tinggi, siswa akan mudah memahami materi yang dipelajari. Bruner menyatakan dalam bukunya bahwa manusia merupakan salah satu pengolah aktif terhadap informasi yang mereka terima dalam memperoleh suatu pemahaman (Husamah et al., 2016).

Pada aktivitas bertanya, hasil pembelajaran siswa di kelas eksperimen lebih baik dibandingkan siswa kelas kontrol. Hal ini dikarenakan rata-rata siswa menyatakan bahwa mereka bertanya untuk memahami materi yang menurut mereka sulit untuk dimengerti. Menurut Ramadhan., (2017) pertanyaan yang diajukan oleh siswa mampu menambah dan membantu menguraikan pengetahuan yang dimiliki oleh siswa. Bruner menyatakan dalam bukunya bahwa manusia merupakan salah satu pengolah aktif terhadap informasi yang mereka terima dalam memperoleh suatu pemahaman (Husamah et al., 2016).

Pada aktivitas mengamati, hasil pembelajaran siswa kelas eksperimen lebih baik dibandingkan siswa kelas kontrol. Hal ini dikarenakan siswa menyatakan bahwa mereka senang melakukan aktivitas tersebut yang dibantu melalui mengamati gambar dan video memudahkan dalam memahami materi yang dijelaskan oleh guru. Menurut Sukmawati., (2013) bahwa penggunaan media gambar ataupun video dapat membantu siswa meningkatkan pemahaman, penyajian materi dan mengaitkan informasi. Albert Bandura dalam bukunya menyatakan bahwa siswa belajar melalui dari pengamatan yang mereka lihat (Sani, 2015).

\section{Hasil Belajar}

Hasil belajar siswa pada kelas PBL dengan metode $\mathrm{CRH}$ berbantuan media crossword dan kelas PBL dengan metode ceramah dapat dilihat dari hasil uji statistik Mann-Whitney pada Tabel 2 berikut.

Tabel 2 Hasil Uji Statistik Mann-Whitney Pada Hasil Belajar Siswa

\begin{tabular}{lr}
\multicolumn{2}{c}{ Test Statistics $^{\mathbf{a}}$} \\
\hline \multicolumn{2}{c}{ NGain_Persen $^{2}$} \\
\hline Mann-Whitney U & 64.000 \\
Wilcoxon W & 389.000 \\
Z & -4.822 \\
Asymp. Sig. (2-tailed) & .000 \\
\hline
\end{tabular}

Tabel 2 di atas menunjukkan bahwa hasil uji statistik Mann-Whitney didapatkan nilai signifikansi sebesar 0,000 , yang artinya terdapat perbedaan hasil belajar kelas PBL dengan metode $\mathrm{CRH}$ berbantuan media crossword dan kelas PBL dengan metode 
ceramah. Perbedaan hasil belajar tersebut dikarenakan (1) penerapan model PBL dengan metode CRH dan model PBL dengan metode ceramah; (2) penggunaan media crossword pada kelas PBL dengan metode CRH.

Siswa yang belajar melalui penerapan model PBL dengan metode $\mathrm{CRH}$ hasilnya lebih baik dibandingkan dengan siswa melalui model PBL dengan metode ceramah. Hal ini dikarenakan siswa melalui model PBL dengan metode $\mathrm{CRH}$ merasa senang dengan pembelajaran tersebut yang melibatkan kerjasama antara siswa satu dengan lainnya, serta kegiatan pembelajaran yang tidak monoton karena diselingi dengan permainan sehingga suasana belajar menjadi tidak menegangkan.

Penerapan model PBL dengan metode CRH membuat siswa menjadi senang dengan pembelajaran karena sekelompok siswa yang mampu menjawab pertanyaan dengan benar harus berteriak "hore" yang menandakan bahwa kelompok tersebut menjawab secara benar. Penerapan model PBL dengan metode CRH dalam pembelajaran juga menjadi salah satu kegiatan belajar untuk mengetahui kemampuan konsep siswa. Melalui penerapan model PBL dengan metode $\mathrm{CRH}$ tersebut diharapkan dapat melatih siswa dalam menyelesaikan masalah dengan kemampuan pemahaman konsep siswa (Budiyanto, 2016). Teori belajar Ivan Pavlov menyatakan bahwa "pentingnya suatu pembelajaran terletak pada metode yang digunakan serta hasil-hasil yang diperoleh dari pembelajaran tersebut" (Dahar, 2011).

Penerapan model PBL dengan metode $\mathrm{CRH}$ ini dibantu dengan penggunaan media crossword yang bertujuan untuk melatih kemampuan daya ingat siswa terhadap materi yang telah dipelajari. Kemampuan siswa dalam mengingat dan memahami materi yang telah dipelajari akan tersimpan pada memori jangka pendek siswa. Jika materi yang dipelajari oleh siswa terus dilakukan pengulangan menggunakan latihan mengerjakan soal-soal, materi tersebut dapat diteruskan ke memori jangka panjang siswa.
Memori jangka panjang siswa dapat menyimpan informasi yang sangat lama, tergantung pada media yang digunakan (Glassman \& Hadad, 2009). Teori belajar dari Atkinson dan Shiffrin menyatakan bahwa "memori jangka panjang siswa akan menyimpan informasi yang dapat digunakan oleh siswa di kemudian hari, yang membuat informasi tersebut dapat bertahan lama dalam pikiran siswa" (Dahar, 2011).

\section{KESIMPULAN}

Berdasarkan hasil dan pembahasan yang telah dijelaskan di atas, dapat disimpulkan sebagai berikut. (1) Terdapat perbedaan aktivitas belajar siswa di kelas PBL degan metode $\mathrm{CRH}$ berbantuan media crossword dan siswa kelas PBL dengan metode ceramah; (2) Terdapat perbedaan hasil belajar siswa melalui model PBL dengan metode CRH berbantuan media crossword dan siswa melalui model PBL dengan metode ceramah yang berdasarkan pada nilai signifikansi uji statistik Mann-Whitney.

\section{UCAPAN TERIMA KASIH}

Artikel ini merupakan publikasi hasil penelitian yang bersumber dari skripsi penulis pada Tahun 2019. Oleh karena itu, penulis mengucapkan terima kasih kepada dosen pembimbing dan pihak di SMP Plus Miftahul Ulum atas bimbingan dan bantuannya demi kesuksesan penelitian ini.

\section{REFERENSI}

Aliwanto. (2017). Analisis Aktivitas Belajar Siswa. Jurnal Konseling GUSJIGANG, 3(1), 64-71.

Ayaz, M. F., \& Sekerci, H. (2015). The Effects of the Constructivist Learning Approach on Student' s Academic Achievement: A Meta-Analysis Study. The Turkish Online Journal of Educational Technology, 14(4), 143-156.

Budiyanto, A. K. (2016). Sintaks 45 Model Pembelajaran dalam Student Centered Learning (SCL). Universitas Muhammadiyah Malang.

Dahar, R. W. (2011). Teori-teori Belajar \& Pembelajaran. PT Gelora Aksara 
Pratama.

Dewi, N. M. M., Parmiti, D. P., \& Riastini, P. N. (2014). Pengaruh Model Pembelajaran Kooperatif Tipe Course Review Horay (CRH) Terhadap Hasil Belajar IPA Pada Siswa Kelas V SD Tahun Pelajaran 2013/2014 di Gugus IV Kecamatan Buleleng. Jurnal Mimbar PGSD, 2(1).

Glassman, W. E., \& Hadad, M. (2009). Approaches to Psychology (Lima). McGraw Hill Companies.

Hamalik, O. (2017). Proses Belajar Mengaja. PT Bumi Aksara.

Husamah, Pantiwati, Y., Restian, A., \& Sumarsono, P. (2016). Belajar dan Pembelajaran. UMM Press.

Indrastuti, W., Utaya, S., \& Irawan, E. B. (2017). Peningkatan Aktivitas dan Hasil Belajar Siswa Melalui Pembelajaran Kooperatif Tipe Make A Match. Jurnal Pendidikan, 2(8), 1037-1042.

Kim, N. J., Belland, B. R., \& Axelrod, D. (2018). Scaffolding for Optimal Challenge in $\mathrm{K}-12$ Problem-Based Learning. Interdisciplinary Journal of Problem-Based Learning, 13(1), 1-24.

Korpi, H., Peltokallio, L., \& Piirainen, A. (2018). Problem-Based Learning in Professional Studies from the Physiotherapy Students , Perspective. Interdisciplinary Journal of ProblemBased Learning, 13(1), 1-19.

Kusumaningrum, A. D. (2013). Peningkatan Aktivitas dan Hasil Belajar Siswa Kelas IV Pada Materi Koperasi Melalui Model Pembelajaran Kooperatif Tipe Student Teams Achivement Devision di SD Negeri Tegalsari 8 Kota Tegal. Skripsi.

Lee, H.-C., \& Blanchard, M. R. (2018). Why Teach With PBL? Motivational Factors Underlying Middle and High School Teachers Use of Problem-Based Learning. Interdisciplinary Journal of Problem-Based Learning, 13(1), 1-19.

Meganingtyas, B. R., Winarni, R., \& Murwaningsih, T. (2019). The Effect of Using Course Review Horay and Talking Stick Learning Methods Towards Social Science Learning Result Reviewed From Learning Interest. International Journal of Educational Research Review The, 4(2),

190-197.

http://www.ijere.com/frontend//articles/p df/v4i2/10pdf.pdf
Merkel, W. (2016). The Potential of Crossword Puzzles in Aiding English Language Learners. TESOL International Association, 7(4), 898-920. https://doi.org/10.1002/tesj.252

Primasari, D. A. (2016). Peningkatan Aktivitas dan Hasil Belajar Siswa Melalui Penerapan Metode Problem Solving pada Mata Pelajaran Matematika Siswa Kelas IV SD Negeri 1 Endang Rejo. Skripsi.

Puspita, N., \& Sabiqoh, N. (2017). Teaching Vocabulary by Using Crossword Puzzle. Jurnal Tadris Bahasa Inggris, 10(2), 308-325.

Putri, N. D. A., Salim, A., \& Sunardi. (2017). The Effectiveness of The Use of Course Review Horay (CRH) Methods to Improve Numeracy Division Skill of Children with Mild Mental Retardation in SLB Negeri Surakarta, Indonesia Year 2016/2017. European Journal of Special Education Research, 2(3), 32-42. https://doi.org/10.5281/zenodo. 252956

Rusman. (2017). Belajar \& Pembelajaran Berorientasi Standar Proses Pendidikan (1st ed.). PT Kharisma Putra Utama.

Sani, R. A. (2015). Inovasi Pembelajaran (Y. S. Hayati (ed.)). PT Bumi Aksara.

Suana, W. (2016). Peningkatan Aktivitas dan Hasil Belajar Siswa pada Pembelajaran IPA dengan Pendekatan Keterampilan Proses. Jurnal Ilmiah Pendidikan Fisika, 5(1), 15-22. https://doi.org/10.24042/jipf

Sugiyono. (2013). Metode Penelitian Kuantitatif Kualitatif dan $R \& D$. Alfabeta.

Widodo, W., Rachmadiarti, F., \& Hidayati, S. N. (2017). Buku Guru Ilmu Pengetahuan Alam untk SMP/MTs Kelas VII (Revisi 201). Kemendikbud.

Widyanimade, Sujana, I. W., \& Negara, I. G. A. O. (2014). Pengaruh Model Pembelajaran Kooperatif Tipe Course Review Horay Berbantuan Media Audio Visual Terhadap Hasil Belajar IPA Siswa Kelas V SD Saraswati 2 Denpasar. Jurnal Mimbar PGSD, 2(1).

Zubaidah, S., Mahanal, S., Yuliati, L., Dasna, I. W., Pangestuti, A. A., Puspitasari, D. R., Mahfudhillah, H. T., Robitah, A., Kurniawati, Z. L., Rosyida, F., \& Sholihah, M. (2017). Buku Guru Ilmu Pengetahuan Alam untuk SMP/MTs Kelas VIII (Revisi 201). Kemendikbud 